\title{
HEARING LOSS IN PATIENTS WITH SHUNT-TREATED HYDROCEPHALUS
}

\author{
Margarita V. Panova ${ }^{1 *}$, Ina E. Geneva ${ }^{1}$, Kalina I. Madjarova ${ }^{2}$, Miroslava N. Bosheva ${ }^{1}$ \\ ${ }^{1}$ Department of Pediatrics and Medical Genetics, Faculty of Medicine, Medical University, Plovdiv, ${ }^{2}$ Clinic \\ of Ear, Nose and Throat Diseases, St. George University Hospital, Plovdiv, Bulgaria
}

\section{ПОТЕРЯ СЛУХА У ПАЦИЕНТОВ С ГИДРОЦЕФАЛИЕЙ, ПРОШЕДШИХ ЛЕЧЕНИЕ ПРИ ПОМОЩИ ШУНТА}

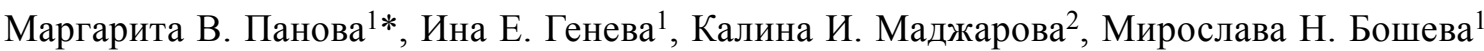 \\ ${ }^{1}$ Кафедра детских болезней и медицинской генетики, Факультет медицины, Медицинский \\ университет, Пловдив, ${ }^{2}$ Клиника оториноларингологии, Университетская больнийа „Свети Георги“, \\ Пловдив, Болгария
}

\begin{abstract}
Hearing loss is a common manifestation of the long-term complications in patients with shunt treated hydrocephalus along with motor development disturbance, cognitive and visual impairment, epilepsy and endocrine disorders.

The aim of the present study was to investigate the alterations of hearing in patients with shunt treated hydrocephalus of non-tumor etiology and at least one year after implantation of ventriculo-peritoneal shunt, as well as their impact on the quality of life of patients.

The study included 70 patients (age range 1.25 years -21.25 years) with shunted non-tumor hydrocephalus and at least one year after placement of the shunt system. Hearing alterations were proved by measuring the brainstem auditory evoked potentials (BAEP) for children up to 5 years of age and children with mental retardation; audiograms was used for children older than 5 years with normal neuro-psychological development (NPD).

Of the 70 studied patients 17 (24\%) had hearing loss (10 bilateral and 7-unilateral) and all of them had sensorineural hearing loss, which is associated with low weight at birth, posthemorrhagic hydrocephalus and brainstem symptoms at the time of diagnosis of hydrocephalus. Hearing pathology was found more often in shunt-treated patients with NPD retardation, poor functional status and low quality of life.

Children with shunt-treated hydrocephalus have hearing loss of sensorineural type. Children with brain stem symptomatology at diagnosing hydrocephalus and children with post-hemorrhagic hydrocephalus show higher risk of hearing loss. Children with shunted hydrocephalus and hearing loss show lower NPD, lower quality of life and lower functional status.
\end{abstract}

Key words: shunted (shunt-treated) hydrocephalus, hearing loss, quality of life, audiometry, brainstem auditory evoked potentials

Folia Medica 2015;57(3\&4):216-222

Copyright (C) 2015 Medical University, Plovdiv

\section{РЕЗЮМЕ}

У пациентов с гидроцефалией, прошедших лечение при помощи шунтирующих систем, расстройство слуха, а также нарушения в двигательном развитии, когниции, зрении, появление эпилепсии и эндокринные нарушения являются частыми проявлениями долгосрочных осложнений. Целью настоящей работы является исследование изменений слуха у пациентов с шунтированной гидроцефалией неопухолевого происхождения, которым как минимум за год до этого установлена вентрикуло-перитонеальная шунтирующая система, а также исследование воздействия данных изменений на качество жизни пациентов. ПАциЕнты и методы: Исследование охватывает 70 пациентов (возрастной охват $1.25-21.25$ лет) с шунтируемой неопухолевой гидроцефалией, которым шунтирующая система установлена как минимум за год до этого. Слуховые изменения были установлены путём измерения слуховых вызванных потенциалов ствола мозга у детей до 5 лет и у детей с умственной отсталостью, аудиометрия была применена в отношении детей старше 5 лет с нормальным нейропсихическим развитием. Результаты: Нейросенсорная потеря слуха была установлена у 17 пациентов (24 \%) (у 10 - двусторонняя и у 7 односторонняя), которая связана у всех с низким весом при рождении, постгемморагической гидроцефалией и симптомами поражений ствола мозга во время диагностирования заболевания. Слуховая патология была установлена чаще у пациентов, прошедших лечение при помощи шунта, у которых установлены отставание в нейропсихическом развитии, плохое функциональное состояние и ухудшенное качество жизни. Выводы: У детей с гидроцефалией, прошедших лечение при помощи шунта потеря слуха является 
нейросенсорного типа. Риск потери слуха повышается у детей с симптоматикой поражений ствола мозга и у детей с постгемморагической гидроцефалией. У детей с шунтируемой гидроцефалией и потерей слуха установлены замедление нейропсихологического развития, ухудшенное качество жизни и ухудшенное функциональное состояние.

Ключевые слова: шунтирующая терапия пригидроцефалии, потеря слуха, качество жизни, аудиометрия, слуховые вызванные потенциилы ствола мозга

Folia Medica 2015;57(3\&4):216-222

(C) 2015 Все права защищены. Медицинский университет, Пловдив

\section{INTRODUCTION}

The introduction of shunt surgery in the neurosurgical practice in the $60 \mathrm{~s}$ of the last century helped overcome the complications as a result of increased intracranial pressure (ICP), increase survival and improve quality of life (QOL) in children with shunt-treated hydrocephalus. The better survival of shunt-treated patients allows for analysis of the complex effect of hydrocephalus and its treatment on their cognition, motor function, hearing, vision, occurrence of epilepsy and endocrine disorders.

Hearing loss is a component of the long-term complications observed in shunted patients. Only a few of the available studies have investigated the incidence of hearing loss in patients with implanted ventriculo-peritoneal shunts (VPS). Löppönen et al. ${ }^{1}$ reported incidence of $38 \%$ of high-frequency sensorineural hearing loss in shunt-treated hydrocephalic children, and Edward et al. ${ }^{2}$ found abnormal BAEP in $68.8 \%$ of the studied infants with hydrocephalus.

Proceeding from the fact that shunt surgery is associated both with resolution and development of auditory dysfunction, Satzer and Guillaume ${ }^{3}$ focused their research on the mechanisms of hearing loss in shunt-treated hydrocephalus. They reported that independent of the indirect mechanisms of hearing loss in shunt-treated patients (mass effect, compromised auditory pathway, complications of premature birth and genetically mediated hydrocephalus with hearing loss), there also exists a direct mechanism (the hydrodynamic theory). According to the latter the very intimate relationship between the cerebrospinal fluid (CSF) and the inner ear fluids permits the origin of relative endo- and perilymphatic hydrops under the conditions of abnormal pressure and abnormal CSF circulation. CSF is associated with the perilymph and the changes in the CSF pressure give rise to alterations of perilymphatic pressure.

Auditory dysfunction may arise in the development of hydrocephalus, as a consequence of shunt operations or as a result of neurosurgical intervention, including puncture and drainage of CSF out of the subdural space. Hearing loss can be categorised into permanent, reversible, early onset, late onset, unilateral and bilateral.

\section{AIM}

The aim of our study was to investigate the alterations of hearing loss in patients with shunt-treated hydrocephalus of non-tumor etiology, at least one year after the implantation of VPS, and also find their effect on the quality of life of patients.

\section{MATERIALS AND METHODS}

The study included 70 patients with shunt-treated non-tumor hydrocephalus studied at least one year after VPS placement. Their mean age was 6.7 years $(1.25-21.25$ years); 36 of the subjects were males and 34 - females. The following groups of hydrocephalus were found according to the etiology: congenital aqueductal stenosis - 18 patients $(25.7 \%)$, hydrocephalus with myelomeningocele (MMC) - 8 patients $(11.4 \%)$, Dandy Walker Syndrome - 5 patients $(7.1 \%)$, chromosomopathy, craniofacial anomalies and congenital cysts - 5 patients (7.1\%), postinfectious hydrocephalus (congenital and acquired) - 6 patients $(8.6 \%)$ and posthemorrhagic hydrocephalus -28 patients $(40 \%)$.

Examination of auditory analyzer was performed using brainstem auditory evoked potentials (BAEP) for children up to 5 years and for children with NPD retardation; for children without NPD retardation above the age of 5 years we used audiograms.

BAEP testing was done with recording electrodes placed as one active electrode placed on mastoid process (A1/A2) and one reference electrode $(\mathrm{Cz})$. BAEP test was performed using monaural click stimulation $11 \mathrm{c} / \mathrm{sec}$. and the average of $2000 \mathrm{re}-$ sponses. Examination was performed at impedance below $5 \mathrm{k} \Omega$ and filters for high frequencies - 3000 $\mathrm{Hz}$, and for low frequencies $-100 \mathrm{~Hz}$. To evaluate BAEP we measured the absolute latency of waves I, III and V and the interpeak intervals I-III, III-V I-V. The examination was performed with patients 
in lying position, after eating, during natural sleep or after sedation with chlorpromazine. As an instrument for auditory screening $30 \mathrm{~dB} \mathrm{nHL}$ is the lowest intensity.

As indicators for abnormal results were accepted increased latencies of wave V or III (or both) and increased interpeak latencies I- V, III $-\mathrm{V}$, with elevated hearing threshold or normal hearing threshold. ${ }^{4}$

For children under 5 years of age with normal mental development we used tonal threshold audiometry to assess the auditory analyzer. The minimum hearing threshold was defined through the air and bone conduction. For examining air conduction the tones were transmitted with the help of earphones and for bone conduction - with the help of an audiometer vibrator. The patients were examined as they had to respond to definite tones of different frequency and intensity with the aim to define the hearing threshold. The level in $\mathrm{dB}$ at which the signal was hardly heard was defined as the minimum hearing threshold. The minimum hearing thresholds were entered into an audiogram. In case of disorder of the sound conducting apparatus of the ear there is sound conductive hearing loss. Hearing loss by air conduction is available. In case of disorder of the sensorineural apparatus (organ of Corti, neurons, sound conduction pathways and central auditory system) there is sensorineural hearing loss. Hearing loss by air and bone conduction is available.

Neuro-psychological development of all patients was examined by a pediatric psychologist. Children up to 3 years of age and those with severe NPD retardation were investigated using ManovaTomova's QOD (quotient of development) scale. IQ (Binet-Termann) was tested in children over the age of 3 years. QOD and IQ results were summarized into a summarized NPD. Mental retardation was defined if tested and calculated IQ was below 70, in accordance with the International Classification of Diseases (ICD 10).

The parents of children above the age of 5 years completed the Hydrocephalus Outcome Questionnaire (HOQ) created by Kulkarni et al. It is applicable to patients between 5-18 years of age no matter what the etiology of hydrocephalus is and at least 6 months after making the diagnosis. The questionnaire consists of 51 questions which concern the physical, cognitive and social-emotional health. The highest assessment score is 1 .

Because of lack of specific test for QOL assessment in patients with hydrocephalus under 5 years of age, their parents completed the Pediatric Quality of life Questionnaire (PedsQL). It includes physical, emotional, social and cognitive health of healthy children, children with acute diseases and children with chronic diseases. The highest assessment score of the answer is 1 . We integrated the results from the investigation of both age categories in a summarized QOL result (total and by domains).

The assessment of the functional status of all patients included in the study was realized using the Functional status scale (FSS) (Pediatrics -2009 American Academy of Pediatrics). It includes examination of mental status, sensorial functioning, communication, motor functioning and respiratory status and feeding. The optimum score is 6 , deterioration of functional status is associated with the increase of the digital value.

\section{Statistical analysis}

The collected primary information was analyzed with SPSS Statistics 19.0, and the diagrams were prepared with Microsoft Office 2010.

The following statistical methods were used: descriptive statistics, non-parametric analysis and graphical analysis. Level of significance for the null hypothesis was accepted at $\mathrm{p}<0.05$.

\section{RESULTS}

Of the 70 studied patients with shunted hydrocephalus 17 patients $(24.3 \%)$ had hearing loss. Ten of these $(14.3 \%)$ did not hear with both ears, and 7 patients (10\%) did not hear with one ear (Fig. 1).

Fifty patients were examined by BAEP testing and 20 were examined using audiometry. We registered auditory sensorineural dysfunction in all patients. Of the 50 patients who were examined by BAEP, 10 patients $(20 \%)$ did not hear with both ears, $4(8 \%)$ did not hear with the right ear and 1 ( $2 \%)$ - with the left ear. Of the 20 patients who were examined by audiogram: 1 patient $(5 \%)$ did not hear with the right ear and $1(5 \%)$ did not hear with the left ear (Fig. 2).

RELATIONSHIP BETWEEN HEARING AND THE REST INDICATORS We found no statistically significant difference in gender for hearing loss when examined by BAEP, audiogram or summarized. There is no statistically significant relationship between hearing and gestation age in shunted patients $\left(p>0.05, \chi^{2}=3.695\right)$.

We found statistically significant difference between hearing and weight at birth $\left(\mathrm{p}<0.05, \chi^{2}=\right.$ 5.598). $70.6 \%$ of the studied children with weight below $2500 \mathrm{~g}$ had hearing loss, while in children 


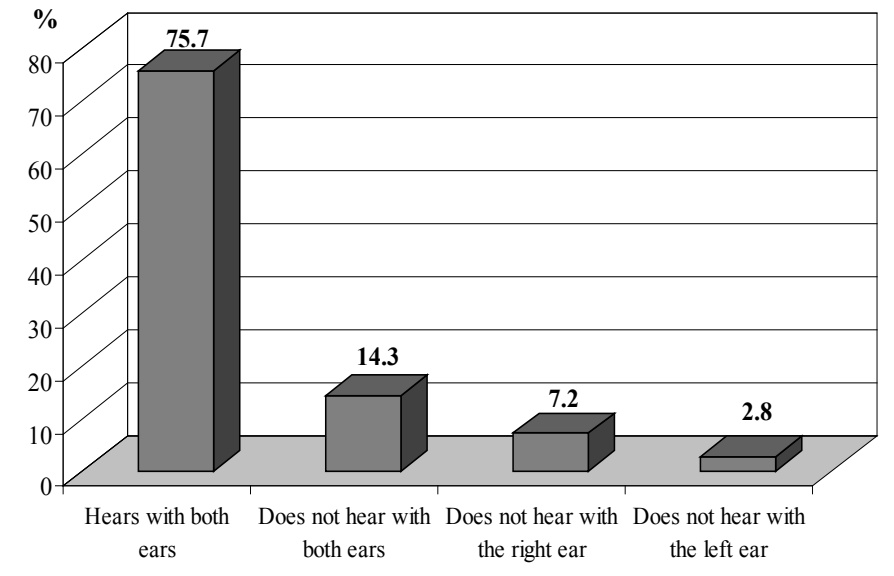

Figure 1. Distribution of patients with hydrocephalus by hearing loss.

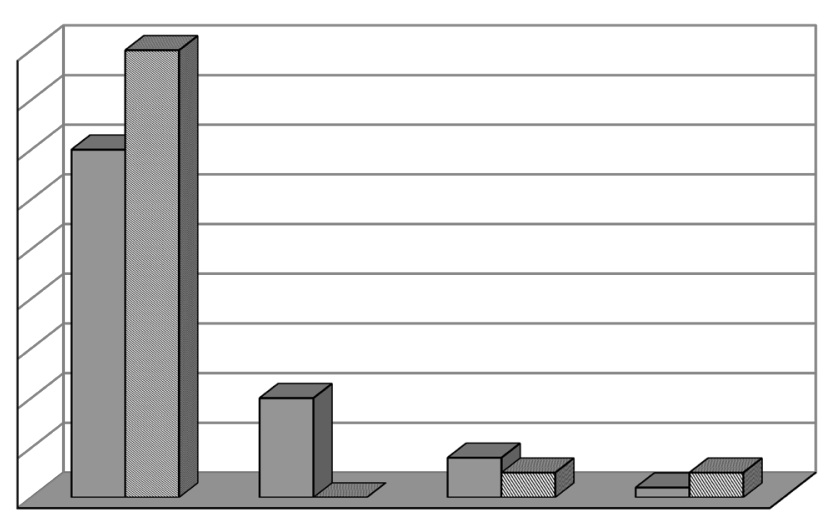

Figure 2. Hearing alterations in patients with shunted hydrocephalus detected by BAEP and audiogram.

with weight over $2500 \mathrm{~g}$ hearing loss was found in $29.4 \%$ (Fig. 3 ).

We found statistically significant difference between hearing and etiology groups of hydrocephalus $\left(p<0.05, \chi^{2}=6.155\right)$. The greatest percentage among patients with hearing loss was found in the group with posthemorrhagic hydrocephalus (Fig. 4).

We found significant difference between hearing and bradypnea as a symptom in the diagnosis of hydrocephalus $\left(p<0.05, \chi^{2}=5.043\right)$. Patients with manifested bradypnea showed higher incidence of hearing loss when hydrocephalus was diagnosed. More than half of the bradypnea patients had hearing loss when hydrocephalus was diagnosed (Fig. 5).

We found statistically significant difference between hearing and abnormalities in respiratory rhythm as a symptom at the time of diagnosing hydrocephalus $\left(\mathrm{p}<0.01, \chi^{2}=7.852\right)$. Patients

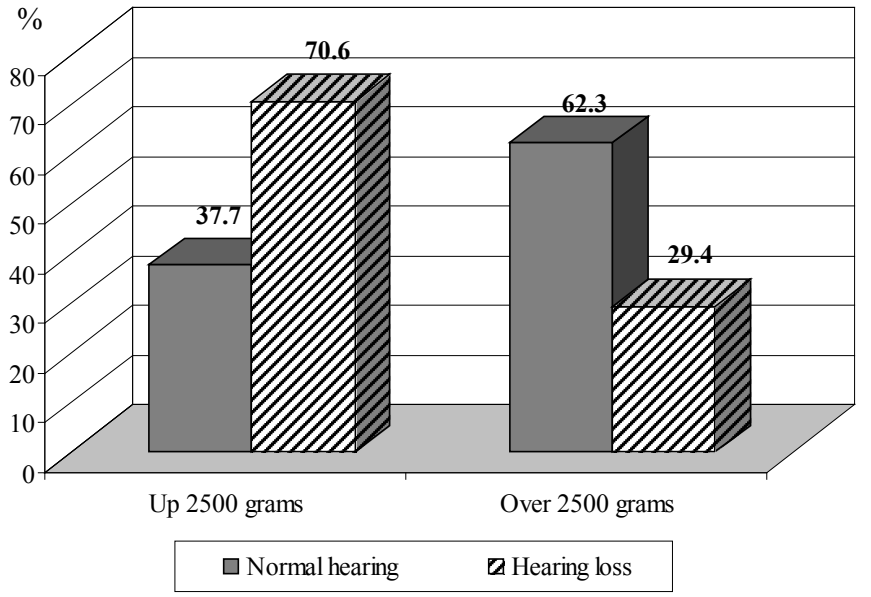

Figure 3. Hearing alterations depending on the weight at birth in patients with shunted hydrocephalus.

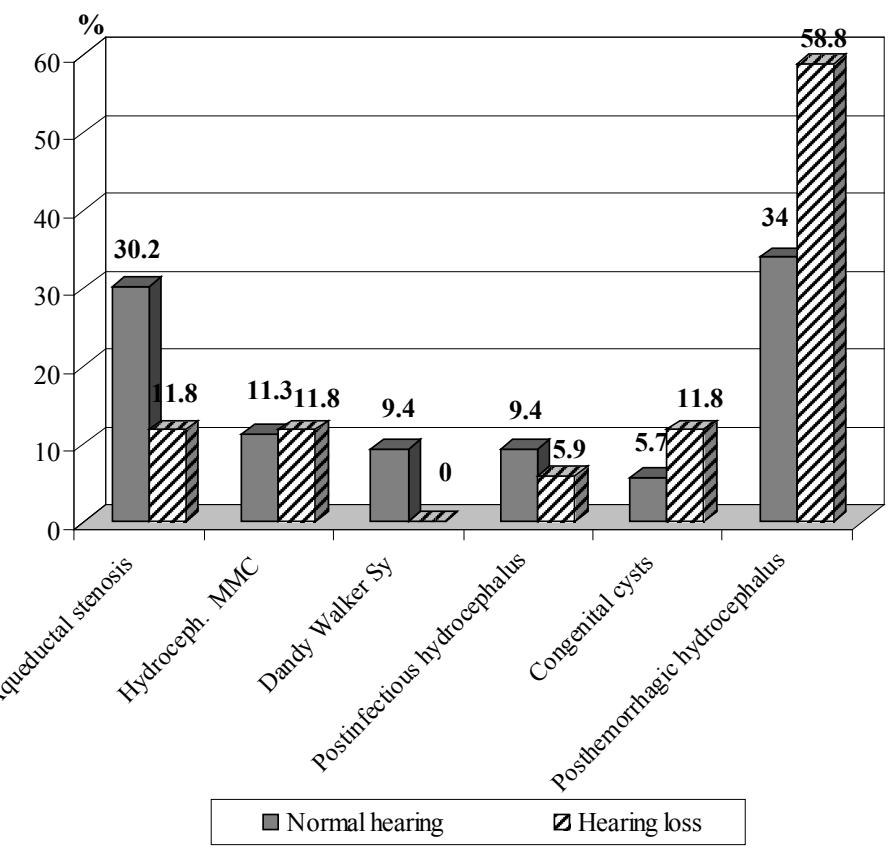

Figure 4. Hearing alterations in different etiology groups of hydrocephalus.

with abnormal respiratory rhythm as a symptom when hydrocephalus was diagnosed showed higher incidence of hearing loss. Most of the patients with abnormal respiratory rhythm had hearing loss when hydrocephalus was diagnosed (Fig. 6).

We did not find statistically significant difference between hearing and delayed placement of a shunting system $\left(p>0.05, \chi^{2}=0.186\right)$, as well as between hearing and the number of revisions of the shunting system $\left(p>0.05, \chi^{2}=1.916\right)$.

The hearing of our patients with shunted hydrocephalus was not affected by mechanical, functional and infectious complications of the shunting system $(\mathrm{p}>0.05)$. 
We did not find higher incidence of hearing loss in patients with shunted hydrocephalus and accompanying child cerebral palsy (CCP) $(\mathrm{p}>$ $0.05, \chi^{2}=3.19$ ).

We found that the incidence of hearing loss was higher among children with shunted hydrocephalus and with severe NPD retardation $\left(\mathrm{p}<0.01, \chi^{2}=\right.$ 11.171) (Fig. 7).

We found association between the incidence of hearing loss and quality of life both as overall health $\left(\mathrm{p}<0.05, \chi^{2}=6.371\right)$ and as physical health alone $\left(\mathrm{p}<0.001, \chi^{2}=13.704\right)$ (Figs 8, 9).

We did not find statistically significant difference between hearing loss and the other elements of quality of life.

We found very high statistically significant association between hearing loss and FSS ( $<<0.001$, $\left.\chi^{2}=22.290\right)-$ children with high FSS values, cor-

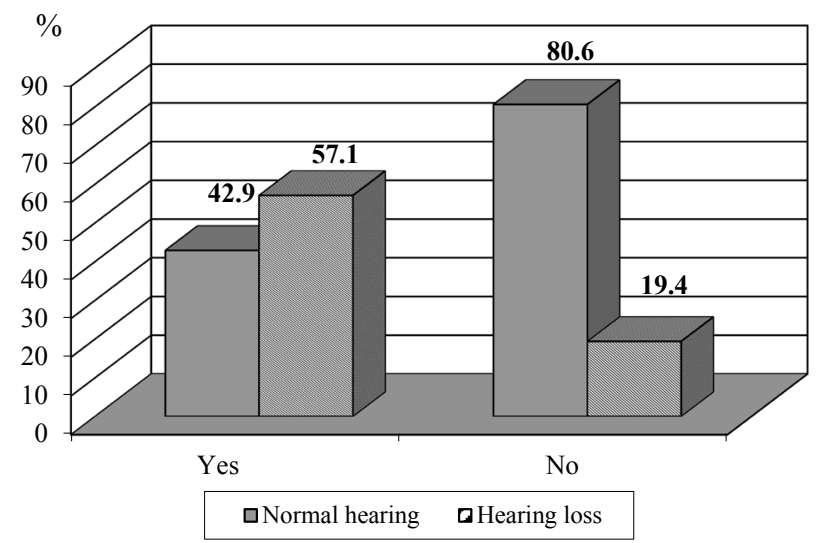

Figure 5. Hearing and bradypnea at the time of diagnosing hydrocephalus in patients who underwent shunting after diagnosing.

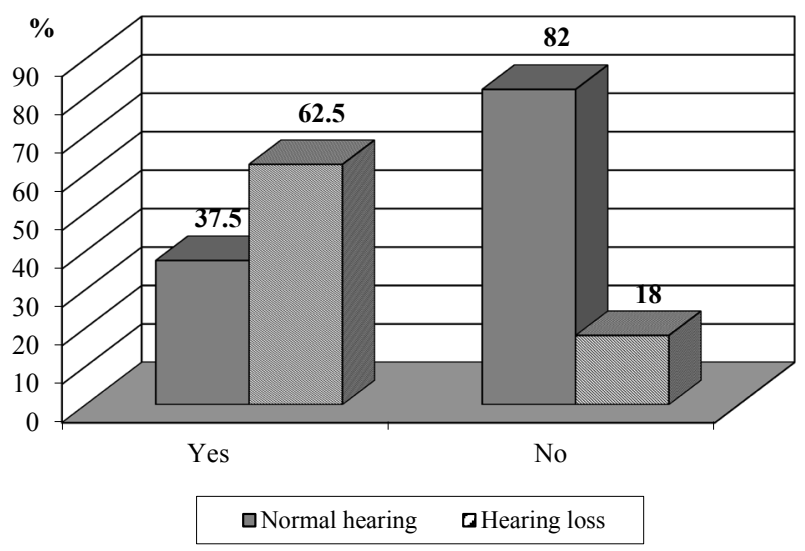

Figure 6. Hearing and abnormal respiratory rhythm when hydrocephalus was diagnosed in patients who underwent shunting after diagnosing. relating with low functional status, showed higher incidence of hearing loss (Fig. 10).

\section{DISCUSSION}

We found hearing loss in $24 \%$ of the patients, a result which is considerably lower in comparison with all reported results in the available literature and is quite similar to the results reported by Löppönen et al. ${ }^{1}$ - 38\%. We cannot comment upon the reasons for hearing loss in the children from our group. We have no information whether hearing loss occurred before the placement of the shunt or whether there was improvement of hearing after shunting. None of the children had prior examination of hearing loss.

Our data concerning sensorineural hearing loss are consistent with the data reported by Löppönen et al. ${ }^{1}$, Sammons et al. ${ }^{7}$, Spirakis and Hurley ${ }^{8}$, and

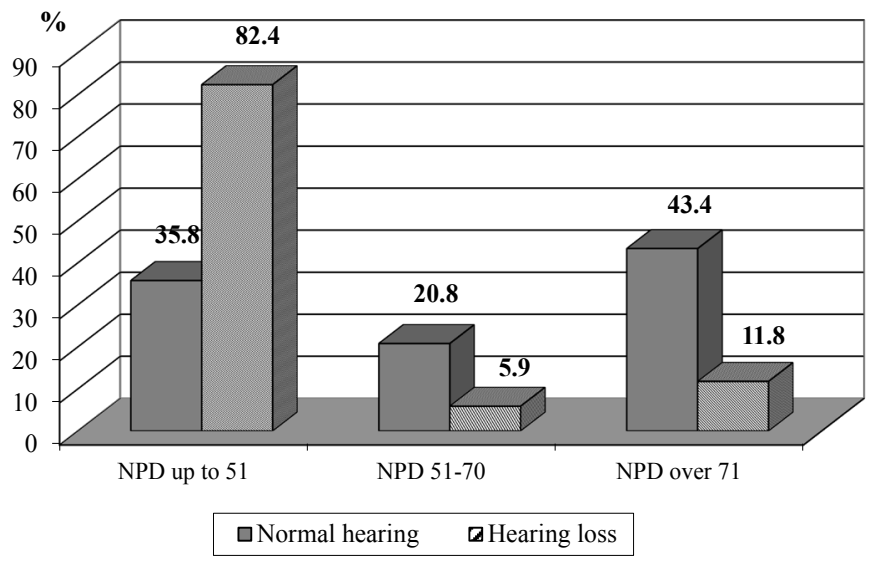

Figure 7. Hearing and summarized results from NPD evaluation QOD Manova-Tomova and IQ.

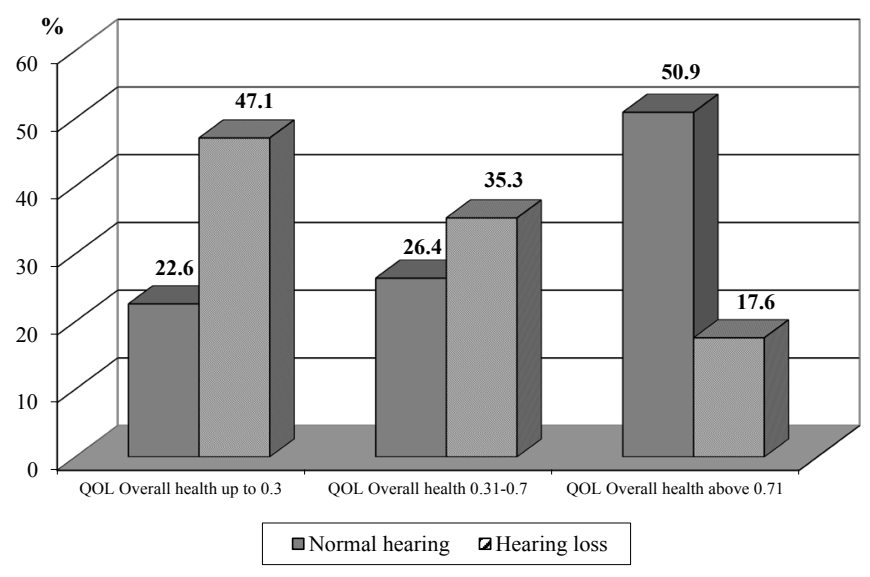

Figure 8. Hearing and quality of life: overall health in patients with shunted hydrocephalus. 


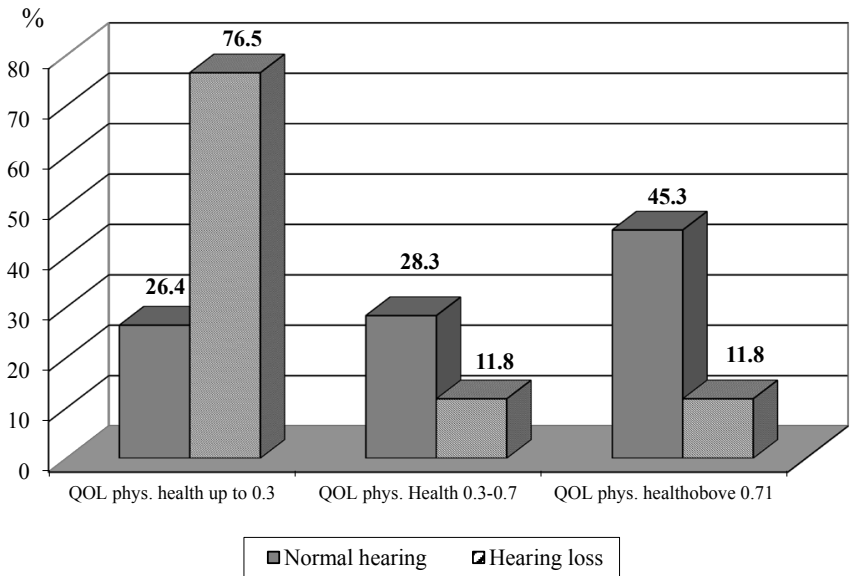

Figure 9. Hearing and quality of life physical health in patients with shunted hydrocephalus.

Sandro et al. (1999) on sensorineural hearing loss in patients with shunt-treated hydrocephalus.

Our study also confirmed the prevalence of bilateral hearing loss reported by Lopponen et al. ${ }^{1}$ and Ducati et $\mathrm{al}^{10}$. We found bilateral hearing deficiency in $58.8 \%$ of the children with hearing loss, which was very close to the results of Löppönen et al. ${ }^{1}$ who found bilateral hearing loss in half of their patients. Our results differ from the results of Spirakis and Hurley ${ }^{8}$, who reported $100 \%$ hearing loss ipsilateral to the inserted CNS catheter - for this reason we cannot confirm the association between hearing loss and the presence of a shunt catheter in spite of the higher percentage of hearing loss ipsilateral of the catheter in our patients.

We corroborated the role of etiology of hydrocephalus as a risk factor for hearing loss which was reported by Kraus et al. ${ }^{11}$ and Ducati et al. ${ }^{10}$. We found normal hearing most often in aqueductal stenosis which was consistent with the data reported by Ducati et al. ${ }^{10}$ The results of our study showed the highest frequency of hearing loss in children with post-hemorrhagic hydrocephalus.

Our results showed higher incidence of hearing loss in patients who, when hydrocephalus was diagnosed, had bradypnea and abnormal respiratory rhythm as manifestations of brain stem symptomatology. So we confirmed the thesis of Kraus et al. ${ }^{11}$ on the importance of brain stem symptomatology as a risk factor for hearing loss in shunt-treated patients.

We also confirm the causal relationship between hearing loss and abnormal NPD, lower quality of life and lower functional status.

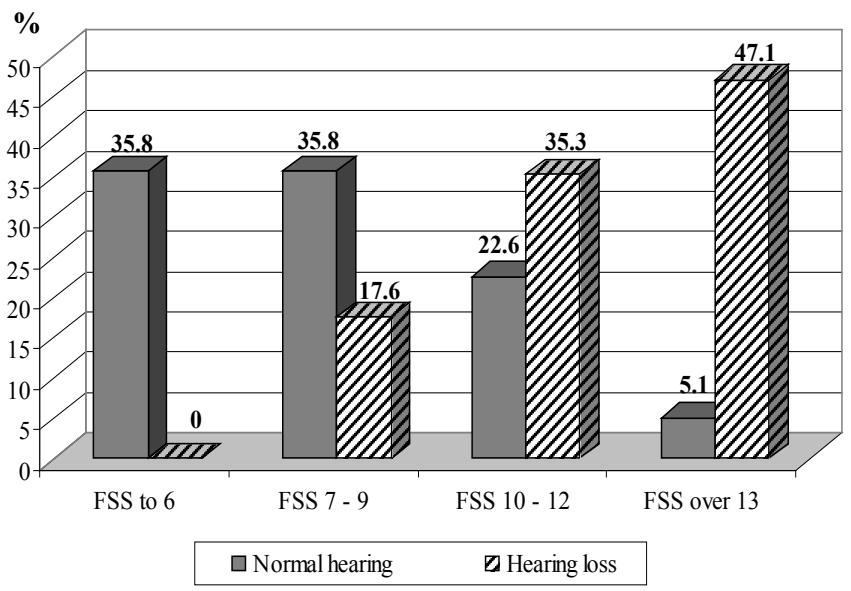

Figure 10. Hearing and FSS in patients with shunted hydrocephalus.

\section{CONCLUSIONS}

1. Children with shunt-treated hydrocephalus have hearing loss of sensorineural type.

2. Children with shunt-treated hydrocephalus and brain stem symptomatology when diagnosing hydrocephalus, as well as children with post-hemorrhagic hydrocephalus show higher risk of hearing loss.

3. Children with shunt-treated hydrocephalus and hearing loss show lower NPD, lower quality of life and lower functional status.

\section{REFERENCES}

1. Löppönen H, Sorri M, Serlo W, von Wendt L. Audiological findings of shunt-treated hydrocephalus in children. Int J Pediatr Otorhinolaryngol 1989;18(1):21-30.

2. Edwards CG, Durieux-Smith A, Picton TW. Auditory brainstem response audiometry in neonatal hydrocephalus. J Otolaryngol Suppl 1985;14:40-6.

3. Satzer D, Guillaume DJ. Hearing loss in hydrocephalus: a review, with focus on mechanisms. Neurosurg Rev 2016;39(1):13-25.

4. Bao X, Wong V. Brainstem auditory-evoked potential evaluation in children with meningitis. Pediatr Neurol 1998;19:109-12.

5. Kulkarni AV, Cochrane DD, McNeely PD, Shams I. Medical, social, and economic factors associated with health-related quality of life in Canadian children with hydrocephalus. J Pediatr 2008;153(5):689-95.

6. Kulkarni AV, Donnelly R, Shams I. Comparison of hydrocephalus outcome questionnaire scores to neuropsychological test performance in school-aged children. J Neurosurg Pediatr 2011;8(4):396-401.

7. Sammons VJ, Jacobson E, Lawson J. Resolution 
of hydrocephalus-associated sensorineural hearing loss after insertion of ventriculoperitoneal shunt. J Neurosurg Pediatr 2009;4(4):394-6.

8. Spirakis SE, Hurley RM. Unilateral hearing loss in children with shunt-treated hydrocephalus. J Am Acad Audiol 2003;14(9):510-7.

9. Stoeckli SJ, Böhmer A. Persistent bilateral hearing loss after shunt placement for hydrocephalus. J Neurosurg 1999;90(4):773-5.
10.Ducati A, Cenzato M, Landi A, Sina C, Villani R. Evaluation of brainstem function, using acoustic evoked potentials, in 26 patients harbouring a CSF shunt for non-tumoral aqueductal stenosis hydrocephalus. J Neurosurg Sci 1986;30(1-2):61-6.

11. Kraus N, Ozdamar O, Heydemann PT, Stein L, Reed NL. Auditory brain-stem responses in hydrocephalic patients. Electroencephalogr Clin Neurophysiol 1984;59(4):310-7. 